\title{
OPTIMALISASI PENGGUNAAN TEKNOLOGI PEMBELAJARAN MAHASISWA PENDIDIKAN MATEMATIKA UNMA BANTEN
}

\author{
(OPTIMIZATION OF THE USE OF MATHEMATICS EDUCATION \\ STUDENTS OF LEARNING TECHNOLOGY UNMA BANTEN)
}

\author{
Deni Pratidiana \\ Universitas Mathla’ul Anwar Banten, denipratidiana@gmail.com
}

\begin{abstract}
Abstrak
Penelitian ini bertujuan untuk melihat optimalisasi penggunaan teknologi pembelajaran oleh mahasiswa program studi pendidikan matematika FKIP UNMA Banten. Penelitian ini menggunakan pendekatan kualitatif dan jenis penelitian deskriptif. Pengambilan subyek penelitian menggunakan teknik purposif. Subyek dalam penelitian ini adalah mahasiswa program studi pendidikan matematika FKIP UNMA Banten yang duduk di semester 2 berjumlah 12 orang mahasiswa yang sedang mengambil mata kuliah aplikasi komputer pendukung pembelajaran. Kesimpulan dari penelitian ini yaitu 1 . Penggunaan teknologi pembelajaran matematika oleh mahasiswa program studi pendidikan matematika FKIP UNMA Banten sudah dilakukan secara optimal. Hal ini dikarenakan ketersediaan fasilitas teknologi di kampus sudah memadai. 2. Subyek penelitian menggunakan teknologi pembelajaran berupa laptop, infokus, dan komputer. Laptop dan komputer sudah di instal dengan aplikasi penunjang seperti Software Microsoft mathematics dan Math Editor.
\end{abstract}

Kata kunci: optimalisasi, teknologi pembelajaran, pendidikan matematika

\begin{abstract}
This study aims to see the optimization of the use of learning technology by students of the mathematics education study program FKIP UNMA Banten?. This study uses a qualitative approach and the type of descriptive research. Taking research subjects using a purposive technique. The subjects in this study were students of the mathematics education study program, FKIP UNMA Banten, who were sitting in semester 2 totaling 12 students who were taking computer application courses to support learning. The conclusions of this study are 1. The use of mathematics learning technology by students of the mathematics education study program FKIP UNMA Banten has been carried out optimally. This is because the availability of technological facilities on campus is adequate. 2. The research subjects used learning technology in the form of laptops, infocus, and computers. Laptops and computers have been installed with supporting applications such as Microsoft mathematics software and Math Editor.
\end{abstract}

Keywords: optimization, learning technology, mathematics education 


\section{PENDAHULUAN}

Dalam beberapa dekade terakhir ini perkembangan ICT (Information and Communication Technology atau TIK (Teknologi Informasi dan Komunikasi) berjalan dengan cepat seiring dengan perkembangan zaman. Kemudahankemudahan yang dialami masyarakat kini bisa dirasakan secara langsung dengan adanya perkembangan teknologi dan munculnya aplikasi-aplikasi canggih yang dapat membantu kegiatan manusia dalam menjalani aktivitas kehidupan seharihari, juga memberikan dampak perubahan terhadap dunia pendidikan khususnya kegiatan pembelajaran. Dengan berkembangnya ICT maka berkembang pula pembelajaran yang berbasis ICT, maka dari itu sudah sewajarnya guru dituntut untuk menguasai teknologi agar mampu mengembangkan materi-materi pembelajaran berbasis ICT dan bisa memanfaatkan ICT sebagai media pembelajaran.

Dewasa ini pembelajaran matematika dan teknologi sudah tidak dapat dipisahkan, ini merupakan satu kesatuan hal penting dalam menciptakan kemudahan dalam belajar matematika. Berbagai cara dan kemudahan bisa diselesaikan dengan adanya teknologi guna memperbaiki dan meningkatkan kegiatan pembelajaran matematika. NCTM (2006) mengemukakan bahwa teknologi berperan sebagai fasilitas dalam pemecahan masalah matematika, komunikasi, penalaran dan bukti. Selain itu, ide-ide matematika yang ada pada siswa bisa dieksplorasi dan di koneksikan di dalam maupun di luar matematika dengan sebaik-baiknya karena teknologi memberikan kesempatan belajar seluasluasnya pada siswa.

Ada sejarah yang cukup panjang dalam pendidikan matematika terkait penggunaan teknologi. Contoh kecil untuk memperkenalkan aritmatika sebagai pendukung perhitungannya masyarakat kebanyakan menggunakan sempoa. Selain itu, sempoa juga dapat menyajikan gambar nyata dan membantu siswa untuk memahami konsep-konsep yang sulit namun cara penggunaan sempoa tidak cepat dan efektif dalam penggunaannya. White board, buku, infocus ini merupakan teknologi yang sering digunakan dalam pembelajaran matematika di zaman sekarang, serta teknologi digital misalnya kalkulator, ponsel, komputer dan internet. Untuk komputer biasanya dilengkapi dengan perangkat lunak yang digunakan dalam konteks matematika misalnya Geogebra, Microsoft Excell, Cabri, GSP, SPSS, Matlab, SketchUp dan lain sebagainya (Stols, 2008).

Berkaitan dengan pengetahuan tentang penggunaan teknologi pembelajaran, Mishra dan Koehler pada tahun 2005 merumuskan sebuah konsep tentang penggunaan teknologi pembelajaran oleh guru maupun calon guru. Hal ini tertuang di dalam TPACK yang merupakan singkatan dari Technological Pedagogical Content Knowledge. TPACK memiliki beberapa komponen penyusun yang saling beririsan antara materi pelajaran (content), pedagogik (pedagogical), dan teknologi (technological) yang berpengaruh pada proses pembelajaran (Mishra dan Koehler, 2008). Untuk menghasilkan pembelajaran berbasis teknologi TRACK menekankan hubungan antara teknologi, isi kurikulum, dan pendekatan pedagogik yang berinteraksi satu sama lain.

Pembelajaran matematika tidak akan terlepas dari teknologi karena sudah menjadi satu kesatuan yang utuh untuk menciptakan inovasi pembelajaran matematika guna memperbaiki dan meningkatkan pembelajaran matematika seutuhnya. NCTM (2006) mengemukakan bahwa teknologi berperan sebagai 
fasilitas dalam pemecahan masalah matematika, komunikasi, penalaran dan bukti. Selain itu, siswa dapat mengeksplorasi ide-ide matematika dan teknologi memberikan kesempatan seluas-luasnya untuk siswa mampu mengkoneksikannya di dalam maupun di luar matematika. Penggunaan teknologi pendidikan dapat dikategorikan sebagai penggunaan teknologi oleh guru (penggunaan pribadi), penggunaan peserta didik, dan penggunaan teknologi untuk meningkatkan pengajaran dan pembelajaran di kelas (Stols, 2008). Penggunaan pribadi yaitu seorang guru mampu menggunakan teknologi untuk menciptakan produktifitas dan profesionalisme dalam bekerja serta membangun komunikasi yang baik antar sesama rekan kerja dalam berbagi pekerjaan (misalnya mengetik tes matematika di Word dan bekerja sama dengan rekan lainnya). Penggunaan peserta didik yaitu seorang peserta didik mampu menggunakan teknologi untuk menciptakan produktifitas belajar dan komunikasi antar mereka terjalin dengan baik (misalnya ponsel, facebook, instagram, penggunaan kalkulator dan lain sebagainya).

Program studi pendidikan matematika FKIP Universitas Mathla'ul Anwar dalam proses perkuliahannya menerapkan proses pembelajaran berbasis teknologi hal ini guna untuk menpersiapkan lulusan-lulusan yang memiliki kompetensi dan pengetahuan tentang teknologi pembelajaran. Hal ini dapat dilihat dari proses belajar mengajar berlangsung, dosen dan mahasiswa mampu mempersiapkan dan menyediakan sebuah presentasi untuk kegiatan pembelajaran. Tentunya ketersediaan fasilitas serta sarana dan prasarana pembelajarannya memadai yang menjadikan hal ini dapat terlaksana. Selain itu, program studi pendidikan matematika FKIP Universitas Mathla'ul Anwar memiliki mata kuliah aplikasi komputer pendukung pembelajaran tujuannya untuk membekali mahasiswa dalam memahami teknologi. Berdasarkan latar belakang masalah yang telah diuraikan di atas, maka rumusan masalah dalam penelitian ini adalah bagaimanakah optimalisasi penggunaan teknologi pembelajaran oleh mahasiswa Program Studi Pendidikan Matematika FKIP Universitas Mathla'ul Anwar?

Adapun tujuan dalam penelitian ini yaitu untuk mengetahui sejauh mana penggunaan teknologi pembelajaran oleh mahasiswa Program Studi Pendidikan Matematika FKIP Universitas Mathla'ul Anwar. Manfaat penelitian ini yaitu:

1) untuk mengetahui penggunaan teknologi pembelajaran oleh mahasiswa Program Studi Pendidikan Matematika FKIP Universitas Mathla'ul Anwar,

2) sebagai masukan untuk mahasiswa Program Studi Pendidikan Matematika FKIP Universitas Mathla'ul Anwar dalam pembelajaran matematika agar dapat menerapkan teknologi yang dapat menunjang motivasi siswa dalam belajar, dan

3) sebagai referensi bagi para pembaca sehingga dapat mengembangkan penelitian lain dengan topik yang berbeda dan lebih luas.

\section{KAJIAN TEORI}

Ilmu pengetahuan itu sangat luas dan sesuatu yang tidak pernah habis untuk dipelajari. Pengetahuan baru berasal dari keinginan manusia yang kuat dan dorongan ingin tahu terhadap sesuatu. Berdasarkan alasan tersebut maka lahirlah sebuah cabang ilmu yang dikenal sebagai filsafat ilmu pengetahuan yang bertujuan mempelajari hakikat dari ilmu pengetahuan tersebut secara rasional (Suhartono, 2008). Ilmu hakikat matematika salah satu ilmu yang dipelajari dalam 
filsafat ilmu pengetahuan. Salah satu ilmu yang dipelajari dalam filsafat ilmu pengetahuan adalah hakikat matematika. Menurut Andi Hakim Nasution (1980) yang dikutip oleh Ahmad Faidi (2013:87) "Istilah matematika berasal dari bahasa yunani, mathein atau mathemein, yang artinya mempelajari. Namun, istilah matematika juga berasal dari bahasa Sanskerta, medha atau widya, yang artinya kepandaian, katahuan, atau inteligensi”.

Berdasarkan uraian hakikat matematika di atas dapat dipahami bahwa hakikat matematika adalah pengetahuan yang terbentuk dari pikiran-pikiran manusia yang menghubungkan ide, proses, dan penalaran agar lebih mudah dipahami dan berguna. Namun demikian, untuk memahami hakikat matematika dengan benar seseorang harus mengalami sendiri proses berpikir. Kegiatan berpikir tersebut memunculkan perasaan keinginan memahami matematika dengan lebih mendalam dan rasa tertarik untuk lebih dalam mengkajinya. Pada akhirnya perasaan tersebut akan mendorong seseorang untuk mengembangkan matematika ketingkat yang lebih tinggi lagi.

\section{A. Pembelajaran Matematika}

Menurut pendapat Ahmad Faidi (2013:86) Matematika adalah ilmu yang mempelajari tentang sesuatu yang abstrak, tidak bisa diraba. Namun kata matematika juga berkaitan dengan kata mathema yang berarti pengetahuan atau ilmu. Hal ini diperkuat oleh Russefendi (1998) yang menyatakan bahwa matematika terbentuk karena pikiran-pikiran manusia, yang berhubungan dengan ide, proses, dan penalaran. Berdasarkan uraian hakikat matematika di atas dapat dipahami bahwa hakikat matematika adalah pengetahuan yang berawal dari ide, proses dan penalaran terhubung dari pikiran-pikiran manusia dan terbentuk menjadi sebuah pengetahuan yang bermanfaat guna membantu pembelajaran menjadi lebih mudah. Namun demikian, proses berpikir seseorang harus terus digali agar bisa memahami hakikat matematika itu sendiri. Hal tersebut bisa memunculkan perasaan keingintahuan memahami matematika lebih mendalam dan rasa tertarik untuk lebih mengkajinya. Pada akhirnya perasaan tersebut akan mendorong seseorang untuk mengembangkan matematika ketingkat yang lebih tinggi lagi.

Slameto (2010:2) mengemukakan, "Belajar adalah suatu proses usaha yang dilakukan seseorang untuk memperoleh suatu perubahan tingkah laku yang baru secara keseluruhan, sebagai hasil pengalamannya sendiri dalam interaksi dengan lingkungannya”. Menurut Wittig yang dikutip oleh Muhibin (2012:65-66) dalam bukunya psychology of learning mendefinisikan belajar sebagai: "any relatively permanent change in an organism's behavioral repertoire that occurs as a result of experience, artinya belajar adalah perubahan yang relatif menetap yang terjadi dalam segala macam atau keseluruhan tingkah laku suatu organisme sebagai hasil pengalaman". Dari pendapat tersebut dapat disimpulkan bahwa belajar merupakan proses perubahan tingkah laku berkat adanya pengalaman yaitu terjalinnya interaksi antara individu dengan lingkungannya.

Hasil Penelitian Usman (2006) menyatakan bahwa "Pembelajaran merupakan suatu proses yang mengandung serangkaian interaksi guru dan siswa atas dasar hubungan timbal balik yang berlangsung dalam situasi edukatif untuk mencapai tujuan tertentu". Sedangkan pembelajaran matematika menurut Suyitno (2004) adalah "Suatu proses interaksi optimal antara guru dengan siswa serta 
antara siswa dengan siswa dalam mempelajari matematika sehingga tercipta iklim dan pelayanan terhadap kemampuan, potensi, minat, bakat, dan kebutuhan siswa tentang matematika yang amat beragam". Dari pendapat di atas dapat disimpulkan bahwa proses interaksi antara guru dengan siswa serta antara siswa dengan siswa dalam mempelajari matematika untuk menanamkan kebiasaan menalar didalam pikiran sehingga mampu mengembangkan berpikir kreatif merupakan proses pembelajaran matematika.

\section{B. Teknologi Pembelajaran}

Suatu keterampilan dan pengetahuan spesifik dalam memanfaatkan sebuah alat untuk mendukung proses pendidikan itu adanya di teknologi pembelajaran. Siswa akan mendapatkan kesempatan untuk memperluas informasi yang tidak terbatas berkat fasilitas teknologi yang tersedia. Perspektif guru tentang Teknologi pembelajaran bukan hanya sekedar teori tapi harus mampu direalisasikan menjadi sebuah inovasi dalam proses pembelajaran matematika. Ketika guru menggunakan komputer atau internet dalam pengajaran, maka alat tersebut dianggap sebagai teknologi pembelajaran (Smaldino et.al, 2012) Teknologi pembelajaran merupakan konsep yang kompleks. Menurut Miarso (2005) teknologi pembelajaran memuat lima perspektif yaitu:

1) Teknologi pembelajaran hanya berfungsi sebagai alat bantu guru dalam mengajar.

2) Teknologi pembelajaran merupakan pendekatan sistem dan teori komunikasi dalam kegiatan pendidikan.

3) Teknologi pembelajaran mencakup manajemen dalam pendidikan.

4) Teknologi pembelajaran memfokuskan perhatian kepada peserta didik agar mereka dapat belajar efektif dan efisien dengan bantuan teknologi.

5) Teknologi pembelajaran lebih memfokuskan dalam menyelesaikan masalah belajar yang dihadapi peserta didik.

Berdasarkan pendapat di atas dapat disimpulkan bahwa teknologi pembelajaran adalah sebuah sistem antara teori dan praktik dalam merancang, mengembangkan, memanfaatkan, mengelola, dan menilai proses belajar dengan memadukan teknologi untuk mempermudah proses pembelajaran. Selain itu, guru wajib membantu siswa menyelesaikan masalah belajar yang berhubungan dengan teknologi.

\section{Teknologi Pembelajaran Matematika}

Pembelajaran matematika tidak bisa dilepaskan dari teknologi karena ini hal penting untuk mentranfer ilmu matematika yang bersifat abstrak. Banyak cara yang digunakan teknologi untuk menciptakan pembelajaran matematika kea rah yang lebih mudah dan menarik. NCTM (2006) mengemukakan bahwa teknologi berperan sebagai fasilitas dalam pemecahan masalah matematika, komunikasi, penalaran dan bukti. Selain itu, teknologi dapat memberikan kesempatan bagi siswa untuk mengeksplorasi ide-ide matematika dan mendukung mereka dalam membuat koneksi baik di dalam maupun di luar matematika. Penggunaan teknologi pendidikan dapat dikategorikan sebagai penggunaan teknologi oleh guru (penggunaan pribadi), penggunaan peserta didik, dan penggunaan teknologi untuk meningkatkan pengajaran dan pembelajaran di kelas (Stols, 2008). Penggunaan pribadi yaitu penggunaan teknologi dapat membuat seorang guru lebih produktif 
dan menjadikan pekerjaan mereka lebih profesional.

Hal ini juga dapat meningkatkan komunikasi dan berbagi pekerjaan dengan rekan-rekan lainnya (misalnya mengetik tes matematika di Word dan bekerja sama dengan rekan lainnya). Penggunaan peserta didik yaitu teknologi yang dapat membuat peserta didik lebih produktif dan meningkatkan komunikasi di antara mereka (misalnya ponsel, facebook, penggunaan kalkulator). Penggunaan teknologi memiliki sejarah panjang dalam pendidikan matematika. Banyak masyarakat memperkenalkan aritmatika dengan sempoa karena dapat mendukung perhitungan. Selain itu, sempoa dapat menyajikan gambar nyata dari matematika dan dapat membantu siswa memahami konsep-konsep yang sulit. Teknologi yang digunakan dalam pembelajaran matematika misalnya OHP, papan tulis, buku, serta teknologi digital misalnya kalkulator, ponsel, komputer, dan internet. Untuk komputer biasanya dilengkapi dengan perangkat lunak yang digunakan dalam konteks matematika misalnya Geogebra, Microsoft Excell, Cabri, GSP, SPSS, Matlab, SketchUp dan lain sebagainya (Stols, 2008).

\section{METODE}

Penelitian ini menggunakan pendekatan kualitatif dan jenis penelitian deskriptif. Pendekatan penelitian kualitatif yaitu untuk mengungkap dan memahami sesuatu di balik fenomena yang akan diteliti (Strauss dan Juliet, 2007). Selain itu pendekatan kualitatif digunakan agar peneliti mendapatkan wawasan tentang sesuatu yang baru diketahui dengan cara mengamati secara langsung objek penelitian. Sedangkan jenis penelitian deskriptif merupakan metode penelitan yang berusaha menggambarkan dan menginterpretasi objek sesuai apa adanya (Sudijono, 2006).

Pengambilan subyek penelitian menggunakan teknik purposif. Menurut Bungin (2007) teknik purposif merupakan teknik pengambilan informan pada penelitian kualitatif dengan cara menentukan kelompok peserta sesuai dengan kriteria terpilih yang relevan dengan masalah penelitian. Agar penelitian efektif dan efisien maka perlu ada ketepatan dalam pemilihan subyek karena akan berpengaruh pada keberhasilan dan kelancaran dalam pengumpulan informasi.

Berdasarkan uraian di atas, subyek dalam penelitian ini adalah mahasiswa Program Studi Pendidikan Matematika FKIP Universitas Mathla'ul Anwar Banten yang duduk di semester 2 berjumlah 12 orang mahasiswa yang sedang mengambil mata kuliah aplikasi komputer pendukung pembelajaran. Alat pengumpul data dalam penelitian ini adalah menggunakan lembar angket, dan lembar wawancara (interview).

Lembar angket ini digunakan untuk mengetahui informasi tentang pemanfaatan teknologi pembelajaran oleh mahasiswa Program Studi Pendidikan Matematika FKIP Universitas Mathla'ul Anwar. Lembar wawancara dalam penelitian ini digunakan untuk menambah informasi terkait hasil jawaban angket mahasiswa tentang pemanfaatan teknologi pembelajaran pada Program Studi Pendidikan Matematika FKIP Universitas Mathla'ul Anwar. 
Tabel 1. Item Pernyataan pada Angket

\begin{tabular}{cl}
\hline No & \multicolumn{1}{c}{ Pernyataan } \\
\hline 1 & Saya menggunakan teknologi pembelajaran matematika \\
2 & $\begin{array}{l}\text { Penggunaan teknologi pembelajaran sangat menyenangkan } \\
\text { Teknologi pembelajaran memberikan manfaat dalam memahami } \\
\text { matematika }\end{array}$ \\
4 & $\begin{array}{l}\text { Fasilitas teknologi pembelajaran yang tersedia di kampus sudah } \\
\text { memadai }\end{array}$ \\
5 & $\begin{array}{l}\text { Mata kuliah Aplikasi Komputer Pendukung Pembelajaran memberikan } \\
\text { banyak pengetahuan untuk saya }\end{array}$ \\
6 & $\begin{array}{l}\text { Saya merasa kesulitan dalam menggunakan teknologi pembelajaran } \\
\text { matematika }\end{array}$ \\
\hline
\end{tabular}

Rimilda (2017: 6)

Wawancara yang digunakan berupa wawancara semi terstruktur. Adapun kisi-kisi wawancara adalah sebagai berikut.

Tabel 2. Pertanyaan Wawancara

\begin{tabular}{cl}
\hline No & \multicolumn{1}{c}{ Pertanyaan Wawancara } \\
\hline 1 & Apa yang Anda ketahui tentang teknologi dan media pembelajaran? \\
2 & Teknologi dan media pembelajaran apa saja yang Anda gunakan dalam \\
& pembelajaran matematika? \\
3 & $\begin{array}{l}\text { Bagaimana tanggapan Anda tentang manfaat dari penggunaan teknologi } \\
\text { dan media pembelajaran matematika? }\end{array}$ \\
& Apa saja teknologi dan media pembelajaran yang Anda pelajari dari mata \\
4 & kuliah media dan teknologi pembelajaran matematika di perkuliahan? \\
\hline
\end{tabular}

Teknik analisis data yang digunakan pada penelitian kualitatif menurut Creswell (2010) melalui langkah-langkah

1) Mengolah dan mempersiapkan data untuk dianalisis.

2) Membaca keseluruhan data.

3) Menganlisis lebih detail dengan meng-coding data. Coding merupakan proses mengolah materi/informasi menjadi segmen-segmen tulisan sebelum memaknainya.

4) Terapkan proses coding untuk mendeskripsikan setting, orang-orang, kategori-kategori yang akan dianalisis.

5) Tunjukkan tentang cara deskripsi dari informasi yang diperoleh akan disajikan kembali dalam narasi/laporan kualitatif.

6) Menginterpretasi atau memaknai data.

\section{HASIL DAN PEMBAHASAN}

Pengoptimalan penggunaan teknologi pembelajaran oleh mahasiswa Program Studi Pendidikan Matematika FKIP Universitas Mathla'ul Anwar Banten berdasarkan jawaban angket dan hasil wawancara disajikan pada uraian di bawah ini. Penulis memaparkan hasil wawancara dan angket 12 orang mahasiswa yang dianggap memiliki respon dan jawaban yang sesuai dengan tujuan penelitian. Adapun hasil penelitian yang dimaksud adalah sebagai berikut. 
Tabel 3. Jawaban Angket Mahasiswa

\begin{tabular}{|c|c|c|c|c|c|c|c|}
\hline \multirow[t]{2}{*}{ No } & \multirow{2}{*}{ Indikator Pertanyaan } & \multicolumn{5}{|c|}{ Jawaban Angket } & \multirow{2}{*}{ Jumlah } \\
\hline & & STS & $\mathrm{TS}$ & $\mathrm{N}$ & $\mathrm{S}$ & SS & \\
\hline 1. & $\begin{array}{ll}\text { Saya } & \text { menggunakan } \\
\text { teknologi } & \text { pembelajaran } \\
\text { matematika } & \end{array}$ & & & 3 & 9 & & 12 \\
\hline 2. & $\begin{array}{lr}\text { Penggunaan } & \text { teknologi } \\
\text { pembelajaran } & \text { sangat } \\
\text { menyenangkan } & \end{array}$ & & & & 10 & 2 & 12 \\
\hline 3. & $\begin{array}{lr}\text { Teknologi } & \text { pembelajaran } \\
\text { memberikan } & \text { manfaat } \\
\text { dalam } & \text { memahami } \\
\text { matematika } & \end{array}$ & & & & 8 & 4 & 12 \\
\hline 4. & $\begin{array}{lr}\text { Fasilitas } & \text { teknologi } \\
\text { pembelajaran } & \text { yang } \\
\text { tersedia di kampus } & \text { sudah } \\
\text { memadai }\end{array}$ & & & & 8 & 4 & 12 \\
\hline 5. & $\begin{array}{l}\text { Mata kuliah Aplikasi } \\
\text { Komputer Pendukung } \\
\text { Pembelajaran memberikan } \\
\text { banyak pengetahuan untuk } \\
\text { saya }\end{array}$ & & & & 5 & 7 & 12 \\
\hline 6. & $\begin{array}{lr}\text { Saya merasa kesulitan } \\
\text { dalam } & \text { menggunakan } \\
\text { teknologi } & \text { pembelajaran } \\
\text { matematika } & \end{array}$ & & & 6 & 6 & & 12 \\
\hline
\end{tabular}

Dari hasil jawaban angket di atas dapat diketahui bahwa subyek penelitian yang berjumlah 12 orang mahasiswa memilih jawaban "S (Setuju)" untuk enam item pernyataan. Jawaban "Setuju" dipilih oleh 9 orang mahasiswa untuk pernyataan yang pertama, 10 orang mahasiswa untuk pernyataan yang kedua, 8 orang mahasiswa untuk pernyataan yang ketiga dan keempat, 5 orang mahasiswa untuk pernyataan yang kelima, dan 6 orang mahasiswa untuk pernyataan yang keenam. Selain itu terdapat 3 orang mahasiswa memberikan jawaban "N" untuk item pernyataan "Saya menggunakan teknologi pembelajaran matematika" dan 6 orang mahasiswa memberikan jawaban "N" untuk item pernyataan "Saya merasa kesulitan dalam menggunakan teknologi pembelajaran matematika" Sedangkan terdapat 2 orang mahasiswa memilih jawaban "Sangat Setuju" untuk pernyataan bahwa penggunaan teknologi pembelajaran sangat menyenangkan dan terdapat 7 orang mahasiswa memilih jawaban "Sangat Setuju" untuk pernyataan bahwa mata kuliah Aplikasi Komputer Pendukung Pembelajaran memberikan banyak pengetahuan untuk mereka.

Hasil jawaban angket di atas diperkuat dengan hasil wawancara. Berikut dipaparkan rangkuman hasil wawancara yang peneliti lakukan terhadap mahasiswa Program Studi Pendidikan Matematika FKIP Universitas Mathla'ul Anwar Banten. 
Tabel 4. Jawaban Wawancara Mahasiswa

\begin{tabular}{cl}
\hline Subyek & \multicolumn{1}{c}{ Respon } \\
\hline Peneliti & $\begin{array}{l}\text { Apa yang Anda ketahui tentang teknologi pembelajaran } \\
\text { matematika ? }\end{array}$ \\
\hline Mahasiswa & $\begin{array}{l}\text { Teknologi pembelajaran matematika adalah suatu sistem yang di } \\
\text { bagun untuk mempermudah pembelajaran matematika dengan } \\
\text { bantuan teknologi. }\end{array}$ \\
\hline Peneliti & $\begin{array}{l}\text { Teknologi dan media pembelajaran apa saja yang Anda gunakan } \\
\text { dalam pembelajaran matematika ? }\end{array}$ \\
\hline Mahasiswa & $\begin{array}{l}\text { Laptop, Infokus, Komputer dan komputer yang sudah di instal } \\
\text { software penunjang pembelajaran matematika contohnya Microsoft } \\
\text { Mathmatics dan Math Editor }\end{array}$ \\
\hline Peneliti & $\begin{array}{l}\text { Bagaimana tanggapan Anda tentang manfaat dari penggunaan } \\
\text { teknologi dan media pembelajaran matematika ? }\end{array}$ \\
\hline Mahasiswa & $\begin{array}{l}\text { Sangat bermanfaat sekali bisa menambah kompetensi dalam } \\
\text { mengajar dan menyampaikan materi matematika dengan mudah } \\
\text { dipahami. }\end{array}$ \\
\hline Peneliti & $\begin{array}{l}\text { Apa saja teknologi dan media pembelajaran yang Anda pelajari dari } \\
\text { mata kuliah Aplikasi Komputer Pendukung Pembelajaran? }\end{array}$ \\
\hline Mahasiswa & Microsoft Mathmatics, Math Editor dan masih banyak yang lainnya \\
\hline
\end{tabular}

Berdasarkan hasil wawancara dapat disimpulkan bahwa mahasiswa sebagai subyek penelitian ini memberikan jawaban dan tanggapan yang positif terhadap penggunaan teknologi pembelajaran matematika di kampus FKIP Universitas Mathla'ul Anwar Banten. Hal ini terlihat pada jawaban responden yang mengungkapkan bahwa mereka mendapatkan pengalaman dan pengetahuan yang bermanfaat dari penggunaan teknologi pembelajaran. Hal ini dapat membantu mereka untuk lebih memahami materi matematika yang bersifat abstrak.

Dari hasil angket dan wawancara di atas dapat diketahui bahwa penggunaan teknologi pembelajaran matematika oleh mahasiswa program studi pendidikan matematika FKIP Universitas Mathla'ul Anwar Banten sudah dilakukan secara optimal. Dengan ketersediaan fasilitas teknologi yang memadai di kampus tersebut dan didukung oleh adanya mata kuliah aplikasi komputer pendukung pembelajaran menjadikan mahasiswa mampu memanfaatkan teknologi pembelajaran dengan efektif dan efisien. Penggunaan teknologi pembelajaran saat ini sangat penting dan berpengaruh terhadap proses pembelajaran terutama pada materi matematika. Hal ini sejalan dengan pendapat NCTM (2006) menjelaskan bahwa teknologi merupakan sarana penting untuk belajar dan mengajar matematika karena dapat mempengaruhi siswa dalam belajar dan meningkatkan prestasinya.

\section{SIMPULAN DAN SARAN}

Dari hasil penelitian dapat disimpulkan bahwa: 1) Penggunaan teknologi pembelajaran matematika oleh mahasiswa program studi pendidikan matematika FKIP Universitas Mathla'ul Anwar Banten sudah dilakukan secara optimal. Hal ini dikarenakan ketersediaan fasilitas teknologi di kampus sudah memadai. 2) Subyek penelitian menggunakan teknologi pembelajaran berupa laptop, infokus, 
dan komputer. Laptop dan komputer sudah di instal dengan aplikasi penunjang seperti Software yang dapat digunakan dalam pembelajaran matematika. Software yang digunakan yaitu Microsoft Mathmatics dan Math Editor.

\section{DAFTAR RUJUKAN}

Bungin, Burhan. (2007). Penelitian Kualitatif. Jakarta: Kencana.

Creswell, John W. (2010). Research Design. Yogyakarta. Pustaka Pelajar.

Faidi, Ahmad. 2013. Tutorial Mengajar untuk Melejitkan Otak Kanan \& Kiri Anak. Jogjakarta: DIVA Press

Miarso, Yusufhadi. (2005). Menyemai Benih Teknologi Pendidikan. Jakarta: Prenada Media.

Mishra, P. dan Koehler, M. J., (2008). Introducing TPACK. AACTE Committee on Innovation and Technology (Ed.), The Handbook of Technological Pedagogical Content Knowledge (TPACK) for Educators (pp. 3-29).

NCTM .(2006). The Role of Technology in the Teaching and Learning of Mathematics.

Rimilda, R. (2017). Pemanfaatan Teknologi Pembelajaran Oleh Mahasiswa Program Studi Pendidikan Matematika Stkip Bina Bangsa Getsempena Banda Aceh. Numeracy Journal, 4(2).

Russeffendi, E.T. (1998). Dasar-Dasar Penelitian Pendidikan dan Bidang NonEksakta Lainnya. Semarang: IKIP Semarang Press.

Slameto. 2010. Belajar Dan Faktor-Faktor Yang Mempengaruhi. Jakarta: Rineka Cipta.

Smaldino, Sharon E., Lowther, Deborah L., dan Russell, James D. (2011). Instructional Technology \& Media for Learning: Teknologi Pembelajaran dan Media Untuk Belajar. Jakarta: Prenada Media Grup.

Stols, Gerrit. (2008). Teaching and Learning of Mathematics Using Technology: Opportunities and Issues. Diakses pada tanggal 5 April 2014, dari http://school-maths.com.

Strauss, Anselm dan Juliet Corbin. (2007). Dasar-dasar Penelitian Kualitatif. Yogyakarta: Pustaka Pelajar.

Sudijono, Anas. (2006). Pengantar Evaluasi Pendidikan. Jakarta: PT. Raja Grafindo Persada.

Suhartono, S. (2008). Filsafat Ilmu Pengetahuan Persoalan Eksistensi dan Hakikat Ilmu Pengetahuan. Yogyakarta: Arruz Media.

Suyitno, Amin. (2004). Dasar-dasar dan Proses Pembelajaran Matematika. Semarang:FMIPA UNNES.

Syah, Muhibbin. 2012. Psikologi Belajar. Jakarta: PT Raja Grafindo Persada.

Usman, M. Uzer. (2006). Menjadi Guru Profesional. Bandung: Remaja Rosdakarya. 